\title{
Distribution and conservation status of the orang-utan (Pongo spp.) on Borneo and Sumatra: how many remain?
}

\author{
Serge A. Wich, Erik Meijaard, Andrew J. Marshall, Simon Hus son \\ Marc Ancrenaz, Robert C. Lacy, Carel P. van SChaik, Jito Sugardjito \\ Togu Simorangkir, Kathy Traylor-Holzer, Matt Doughty \\ Jatna Supriatina, Rona Dennis, Melvin Gumal, Cheryl D. Knott \\ and IAN SINGLETON
}

\begin{abstract}
In recognition of the fact that orang-utans (Pongo spp.) are severely threatened, a meeting of orangutan experts and conservationists, representatives of national and regional governmental and non-governmental organizations, and other stakeholders, was convened in
\end{abstract}

SERge A. Wich (Corresponding author) Great Ape Trust of Iowa, 4200 SE 44th Avenue, Des Moines, IA, 50320, USA. E-mail swich@greatapetrust.org

ERIK MeijaArd Orang-utan Conservation Services Program, Balikpapan, Indonesia, and Tropical Forest Initiative, The Nature Conservancy, Balikpapan, East Kalimantan, Indonesia.

Andrew J. Marshall Department of Anthropology and Graduate Group in Ecology, University of California, Davis, USA.

Simon Husson Wildlife Research Group, Department of Anatomy, University of Cambridge, UK.

Marc Ancrenaz Kinabatangan Orang-Utan Conservation Project, Sandakan, Sabah, Malaysia.

Robert C. LaCY* and Kathy Traylor-Holzer IUCN/SSC Conservation Breeding Specialist Group, Apple Valley, USA.

CAREL P. VAN SCHAIK Anthropological Institute \& Museum, University of Zürich, Switzerland.

Jito Sugardjito Fauna \& Flora International-Indonesia Programme, Kompleks Pusat Laboratorium UnivNasional, Ragunan, Jakarta, Indonesia.

Togu Simorangkir Yayorin (Yayasan Orang-utan Indonesia), Pangkalan Bun, Central Kalimantan, Indonesia.

Matt Doughty UNEP-World Conservation Monitoring Centre, Cambridge, UK.

Jatna Supriatna Conservation International-Indonesia Programme, Jalan Pejaten Barat, Kemang, Jakarta, Indonesia.

RonA DENNis Center for International Forestry Research, Bogor, Indonesia. Melvin Gumal Wildlife Conservation Society-Malaysia, Kuching, Sarawak, Malaysia.

Cheryl D. Knott Harvard University, Department of Anthropology, Peabody Museum, Cambridge, USA.

Ian Singleton Sumatran Orang-utan Conservation Programme, Medan, Indonesia.

${ }^{*}$ Also at: Department of Conservation Biology, Chicago Zoological Society, Brookfield, USA.

Received 31 October 2007. Revision requested 22 January 2008.

Accepted 4 March 2008.
Jakarta, Indonesia, in January 2004. Prior to this meeting we surveyed all large areas for which orang-utan population status was unknown. Compilation of all survey data produced a comprehensive picture of orang-utan distribution on both Borneo and Sumatra. These results indicate that in 2004 there were $c$. 6,500 P. abelii remaining on Sumatra and at least 54,000 P. pygmaeus on Borneo. Extrapolating to 2008 on the basis of forest loss on both islands suggests the estimate for Borneo could be $10 \%$ too high but that for Sumatra is probably still relatively accurate because forest loss in orang-utan habitat has been low during the conflict in Aceh, where most P. abelii occur. When those population sizes are compared to known historical sizes it is clear that the Sumatran orang-utan is in rapid decline, and unless extraordinary efforts are made soon, it could become the first great ape species to go extinct. In contrast, our results indicate there are more and larger populations of Bornean orang-utans than previously known. Although these revised estimates for Borneo are encouraging, forest loss and associated loss of orang-utans are occurring at an alarming rate, and suggest that recent reductions of Bornean orang-utan populations have been far more severe than previously supposed. Nevertheless, although orang-utans on both islands are under threat, we highlight some reasons for cautious optimism for their long-term conservation.

Keywords Borneo, decline, great ape, orang-utan, Pongo, Sumatra.

\section{Introduction}

rang-utans (Pongo spp.) are the only great apes found in Asia. During the Pleistocene they occurred throughout South-east Asia, from southern China in the north to Java in the south (von Koeningswald, 1982; Bacon \& Long, 2001). Today their distribution is restricted to the islands of Sumatra and Borneo (Rijksen \& Meijaard, 1999; Singleton et al., 2004), with those on each island being 
generally regarded as unique species $(P$. abelii on Sumatra and P. pygmaeus on Borneo; Groves, 2001; Warren et al., 2001). The Bornean species is generally regarded to comprise three subspecies: P. pygmaeus pygmaeus, P. p. wurmbii and P. p. morio (Groves, 2001).

In addition to large-scale habitat conversion, destruction and fragmentation (Holmes, 2000; Jepson et al., 2001), and hunting for food and the pet trade (Rijksen \& Meijaard, 1999; Marshall et al., 2006), their large body size (Harvey et al., 1987) and long inter-birth interval (6.1-9.3 years, Galdikas \& Wood, 1990; Wich et al., 2004), make orangutans particularly vulnerable to extinction (Leighton et al., 1995; Singleton et al., 2004; Marshall et al., in press). Adding to their vulnerability are the facts that orang-utans live at low densities (ranging from near zero to $7 \mathrm{~km}^{-2}$; van Schaik et al., 1995, 2001, 2005; Morrogh-Bernard et al., 2003; Wich et al., 2004b; Johnson et al., 2005), occupy large home ranges (Singleton \& van Schaik, 2001), are mainly restricted to lowland rainforest areas (Rijksen \& Meijaard, 1999) and are increasingly restricted to small forest fragments (Wich et al., 2003; Singleton et al., 2004). As a result the Sumatran orang-utan is currently categorized as Critically Endangered on the IUCN Red List (IUCN, 2007), and the Bornean orang-utan as Endangered.

Recognizing the fact that ecological extinction of orang-utans could be only decades away (Rijksen \& Meijaard, 1999; Singleton et al., 2004; Meijaard \& Wich, 2007), a group of orang-utan conservation scientists and relevant stakeholders met in 2004 to update distribution maps and life history data and to develop a population and habitat viability assessment model. No such update had been made since the mid 1990s (Rijksen \& Meijaard, 1999) but such information is urgently needed to guide conservation planning. We report here the status and trends of orang-utan populations as discussed in the 2004 workshop along with results from more recent surveys. The results of the population and habitat viability modelling exercises are reported elsewhere (Marshall et al., in press). We conclude with recommendations for urgent conservation actions.

\section{Methods}

\section{Distribution and habitat assessment}

Using LANDSAT images from 2002 of North Sumatra and Aceh we produced a comprehensive and detailed map of vegetation coverage, which we overlaid on an elevational data set. We identified key forests for orang-utans in Sumatra according to inferred geographical boundaries or to known variations in orang-utan density between areas at similar altitudes. Thus we identified five areas of primary dry-land forest, and three swamp forests north and west of Lake Toba. Two additional dry-land forest orang-utan populations are known to the south of Lake Toba and these were examined separately using up-to-date information from surveys.

Density estimates were derived from extensive linetransect surveys (Wich et al., 2003, 2004b; Singleton et al., 2004; Wich et al., unpubl. data). Because Sumatran orang-utans are known to respond negatively to selective logging (Husson et al., in press) and because we knew that areas identified from satellite imagery as degraded were heavily damaged, we ignored such areas in our density estimates. Furthermore, field knowledge indicates that less heavily degraded areas were sometimes included as primary forest during the digitizing process (which has led to overestimates of populations in most areas). Thus, we assumed that the small errors produced by ignoring disturbed forests and by including some disturbed forests into the primary forest class would tend to cancel each other out. Nonetheless, we acknowledge some uncertainty in the estimates derived.

For Kalimantan, Indonesian Borneo, we used an existing presence/absence data set for Bornean orang-utan ( $P$. pygmaeus; Rijksen \& Meijaard, 1999) as a baseline distribution map. We updated this knowledge with new density estimates and presence/absence information obtained in 2003, updated with surveys in 2006 and 2007. We combined this new data set with a 2002 forest/non-forest classification, using imagery from the Moderate Resolution Imaging Spectrometer (MODIS, spatial resolution $500 \times 500 \mathrm{~m}$ ). The classification, based on imagery for 10 February-22 April 2002, created composite reflectance images largely free of cloud and other atmospheric perturbations. These were classified using standard image processing algorithms to derive a forest/non-forest map of Borneo (Fuller et al., 2004). We visually compared the 2002 forest/non-forest cover with the baseline distribution map (Rijksen \& Meijaard, 1999), and used this and recent information from the field to update digitally boundaries for the remaining orang-utan habitat using the geographical information system (GIS) ArcView $v 3.2 a$ (ESRI, Redlands, USA). The accuracy of the classification was checked against a number of sources, including 2002 Landsat ETM imagery and the forest/ non-forest classification provided by the Indonesian Ministry of Forestry, which is based on 1999-2000 satellite data. This was done by converting classifications to a raster format and assessing the amount of overlap between the different classifications. In comparison with the Ministry of Forestry classification, ours overestimated orang-utan habitat in $4.8 \%$ of the grid cells (i.e. our classification suggested that orangutan habitat existed in certain areas that the Ministry of Forestry classified as non-forest). About $27 \%$ of the grid cells classified as non-habitat in our map were classified as forest areas by the Ministry of Forestry classification. Taking into consideration that the latter is based on 1999-2000 data and that the Kalimantan forest area declines by $c .10,000 \mathrm{~km}^{2} \mathrm{yr}^{-1}$ 
(Barber et al., 2002) this justifies a $5 \%$ margin of error for our estimates of forest area in Kalimantan.

In Sabah (Malaysian Borneo), orang-utan surveys were conducted in 2002 and 2003 by Ancrenaz et al. (2005) using nest count techniques from helicopters and ground surveys. The results of the ground and aerial surveys were processed with a GIS using a combination of administrative maps and satellite images. Based on aerial observation, each block was stratified according to disturbance type (no disturbance; old- or recently exploited forest; on-going exploitation; disturbed swamp forest), and disturbance and site-specific density estimates were multiplied by the size of orang-utan habitat in that area. As opposed to Kalimantan, where only c. $50 \%$ of the total orang-utan distribution was surveyed, the Sabah surveys covered the entire distribution range. Presence data and density estimates in Sabah therefore provide a better representation of the actual occurrence of orang-utans than in Kalimantan. For Sarawak we do not have sufficient data for analysis.

\section{Results}

\section{Sumatra}

All areas in Sumatra where orang-utans occur are in the northern part of the island (Fig. 1) and we estimate the population is $c .6,624$ (Tables 1-2). This is a sharp reduction from the previous estimate of 7,501 orang-utans (Singleton et al., 2004). This reduction is mainly because an 8-week survey in 2007 in the northern part of Aceh (Ulu Masen and surrounding regions) revealed virtually no orang-utans in an area that had been thought to contain $c$. 800 (Wich, 2007). Subsequently the number of orang-utans that were previously estimated to occur in this area were subtracted from the original total estimate of 7,501 orang-utans (Singleton et al., 2004). Of the remaining populations on Sumatra only three contain $>1,000$ individuals and an additional three contain $1,000>250$ individuals, which is considered the size of a viable population (Marshall et al., in press). The Leuser Ecosystem (Fig. 1) is clearly the stronghold for the Sumatran orang-utan, with c. $91 \%$ of all Sumatran orangutans occurring within its boundaries. Most of this area consists of high mountains, and orang-utans primarily exist around the periphery where they depend on the remaining lowlands. It is in these lowlands that the three largest $\left(>_{1,000}\right.$ individuals) Sumatran orang-utan populations occur (Table 1). Outside the Leuser Ecosystem the most important orang-utan population occurs in what is referred to as the Batang Toru area south of Lake Toba.

\section{Borneo}

We identified 306 geographically distinct forest areas (separated from adjacent areas by rivers or cleared land
$>_{1} \mathrm{~km}$ wide) on Borneo in which we expect orang-utans to occur. Our data indicate that the total $P$. pygmaeus population is at least 54,000 , in three subspecies, with 44 populations containing $>100$ animals (Tables 1-2; data for the East Kalimantan and Sabah populations of P. p. morio are presented separately because these populations may need to be classified as distinct subspecies; Meijaard \& Groves, unpubl. data). The actual total, including all the small populations with $<100$ individuals will be considerably higher.

P. p. pygmaeus (Fig. 2) is the most severely threatened subspecies, with a total of only 3,000-4,500 individuals in north-west Borneo, including Sarawak (Fig. 2). The Lanjak Entimau and Betung Kerihun protected areas are the most important and contain populations of $>1,000$ individuals (Table 1). There are only two other areas that contain $>250$ orang-utans (Ancrenaz, 2007).

P. p. wurmbii is the most numerous subspecies, with an estimated total of $>34,975$ individuals. Most of these occur in the province of Central Kalimantan, in 10 populations of $>1,000$ individuals and seven of $>250$ individuals (Table 1). This subspecies is also represented by the largest populations, such as those in Sebangau, Tanjung Puting, and the Arut-Belantikan area (Fig. 2), which all support $>6,000$ individuals (Table 1 ).

P. p. morio (Fig. 2) survives in several smaller populations in the province of East Kalimantan (c. 4,800), and in larger numbers in the Malaysian state of Sabah (c. 11,000). In addition, preliminary survey work in the heavily degraded forests around the Kutai National Park has revealed that large numbers $(\geq 2,500)$ of orang-utans may survive there but more information is needed before these findings can be included in the density estimate for this subspecies. The East Kalimantan and Sabah populations of P. p. morio may be distinct taxa (Meijaard \& Groves, unpubl. data), in which case the former would be severely threatened, with c. 4,800 animals remaining in several geographically distinct populations (Table 1, Fig. 2). In East Kalimantan only the Kelai and adjacent Telen/Wahau watershed areas contain $>1,000$ individuals and, in addition, there are only three areas with populations $>250$ individuals. In Sabah there are four areas with $>1,000$ orang-utans and an additional three with $>250$. By far the largest of these is the Segama population, with 4,584 orang-utans.

\section{Population trends}

Because estimates of orang-utan density based on a standardized methodology have become available only recently (van Schaik et al., 1995) it is not possible to assess accurately the long-term decline of orang-utans for any of the areas where they occur. Genetic studies, however, indicate that orang-utans in certain areas are in serious decline (Goossens et al., 2006) and this is likely to be similar for many areas 


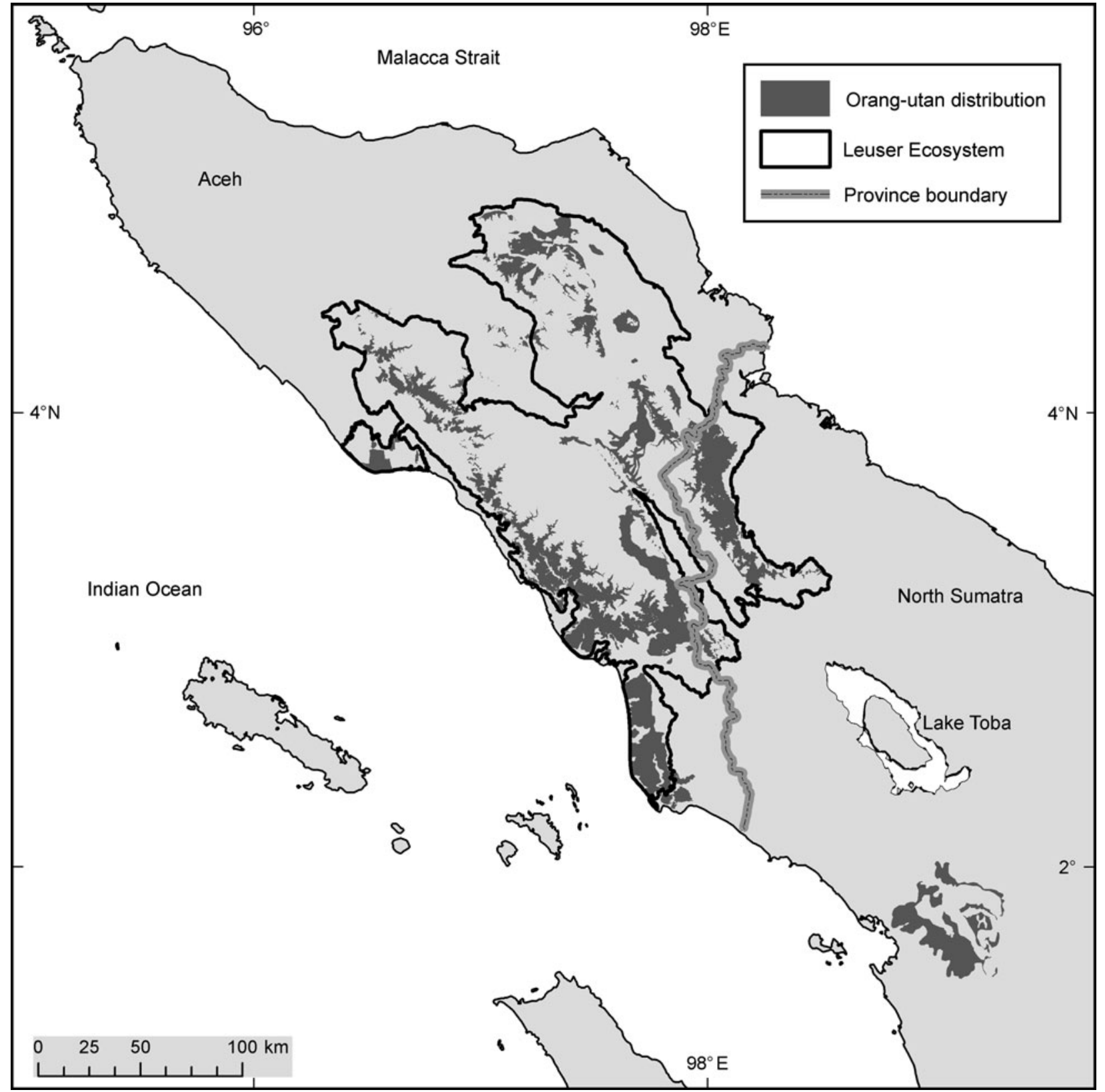

Fig. 1 Distribution of the Sumatran orang-utan P. abelii. The original version of this map was produced by the Sumatran Orang-utan Conservation Programme and the Leuser Management Unit and has been updated based on 2007 survey work in Aceh Province by Fauna \& Flora International in collaboration with the Great Ape Trust.

where they occur. Nevertheless, forest loss can be used as an indication of orang-utan decline. Assumptions associated with this method are (1) we know whether or not the forests that have been lost contained orang-utans, and (2) nonforest vegetation does not offer habitat for viable orangutan populations. Such an approach can only be used for areas that have been surveyed since the early 1990s, when systematic surveys were first used to determine the presence and density of orang-utans in forest blocks throughout their range. Before that time orang-utan distribution was not known in sufficient detail and therefore fails to fulfil the first assumption. The second assumption does not always hold as orang-utans have been found in degraded areas (Marshall et al., 2006). In addition, the degree of forest loss is not known for all areas and our results in this respect should therefore be considered cautiously. In Kalimantan our results indicate that during 1992-2002 the total area of habitat for $P$. pygmaeus decreased from $c$. 141,500 to $c .85,835$ $\mathrm{km}^{2}$, i.e. a $39 \%$ decline. The decrease is not all caused by habitat loss. Several areas, including the upper Melawi watershed in West Kalimantan, and the Mueller and Schwaner Ranges that were partly included by Rijksen \& Meijaard (1999) in their orang-utan distribution maps, are now thought not to contain breeding populations of 
TAble 1 Estimated numbers of P. abelii on Sumatra (Fig. 1) and P. p. pygmaeus, P. p. wurmii and P. p. morio on Borneo (Fig. 2) by habitat unit, and the area of suitable remaining orang-utan habitat within each such unit (and also, for Sumatra only, by habitat block within each unit).

\begin{tabular}{|c|c|c|c|c|}
\hline Species & Habitat unit & $\begin{array}{l}\text { Estimated no. of } \\
\text { individuals }\end{array}$ & Habitat block & $\begin{array}{l}\text { Orang-utan } \\
\text { habitat }\left(\mathrm{km}^{2}\right)\end{array}$ \\
\hline \multirow[t]{18}{*}{ P. abelii } & $\mathrm{W}$ middle Aceh & 103 & $\begin{array}{l}\text { Beutung } \\
\text { (W Aceh) }\end{array}$ & 261 \\
\hline & & & Linge & 10 \\
\hline & E middle Aceh & 337 & Bandar-Serajadi & 555 \\
\hline & W Leuser & 2,508 & $\begin{array}{l}\text { Kluet Highlands } \\
\text { (SW Aceh) }\end{array}$ & 934 \\
\hline & & & W Mt Leuser & 594 \\
\hline & & & Kluet swamp & 125 \\
\hline & & & E Mt Leuser/Kemiri & 273 \\
\hline & & & Mamas-Bengkung & 621 \\
\hline & Sidiangkat & 134 & $\begin{array}{l}\text { Puncak Sidiangkat/ } \\
\text { B. Ardan }\end{array}$ & 186 \\
\hline & E Leuser & 1,052 & Tamiang & 375 \\
\hline & & & Kapi \& Upper Lesten & 220 \\
\hline & & & Lawe Sigala-gala & 198 \\
\hline & & & Sikundur-Langkat & 674 \\
\hline & Tripa swamp & 280 & $\begin{array}{l}\text { Tripa (Babahrot) } \\
\text { swamps }\end{array}$ & 140 \\
\hline & Trumon-Singkil & 1,500 & $\begin{array}{l}\text { Trumon-Singkil } \\
\text { swamps }\end{array}$ & 725 \\
\hline & E Singkil swamps & 160 & E Singkil swamps & 80 \\
\hline & W Batang Toru & 400 & W Batang Toru & 600 \\
\hline & E Sarulla & 150 & E Sarulla & 375 \\
\hline Subtotal & & 6,624 & & 6,946 \\
\hline \multirow{5}{*}{ P. p. pygmaeus } & Batang Ai (Sarawak) & $119-580$ & & 240 \\
\hline & Lanjak Entimau (Sarawak) & $1,024-1,181$ & & 1,688 \\
\hline & Betung Kerihun & $1,330-2,000$ & & 4,500 \\
\hline & Danau Sentarum & 500 & & 1,090 \\
\hline & $\begin{array}{l}\text { Upper Kapuas swamps } \\
\text { (S of Kapuas River, } \\
\text { N of Melawi })^{1}\end{array}$ & $?$ & & $?$ \\
\hline Subtotal & & $3,000-4,500$ & & $<7,500$ \\
\hline \multirow[t]{19}{*}{ P. p. wurmbii } & Gunung Palung & 2,500 & & 900 \\
\hline & Bukit Baka & 175 & & 350 \\
\hline & Bukit Rongga \& Parai & 1,000 & & 4,200 \\
\hline & Tanjung Puting & 6,000 & & 4,150 \\
\hline & Lamandau & 1,200 & & 760 \\
\hline & Mawas & 3,500 & & 5,010 \\
\hline & Sebangau & 6,900 & & 5,780 \\
\hline & Ketingan & 3,000 & & 2,800 \\
\hline & Rungan Kahayan & 1,000 & & 2,000 \\
\hline & Arut Belantikan & 6,000 & & 5,100 \\
\hline & Seruyan & 1,000 & & 3,000 \\
\hline & Bukit Raya & 500 & & 500 \\
\hline & Sei Kahayan \& Sei Sambah & 1,000 & & 1,500 \\
\hline & Sei Sambah \& Sei Katingan & 500 & & 1,000 \\
\hline & Sebangau Kahayan & 700 & & 700 \\
\hline & Kahayan Kapuas & 300 & & 4,000 \\
\hline & Tanjung Keluang & 200 & & 2,000 \\
\hline & Cagar Alam Pararaum & $>500$ & & 500 \\
\hline & Cagar Alam B. Spt & $>500$ & & $>2,000$ \\
\hline Subtotal & & $>34,975$ & & $>46,250$ \\
\hline \multirow{2}{*}{ P. p. morio (in E Kalimantan) } & Kutai National Park & 600 & & 750 \\
\hline & $\begin{array}{l}\text { Lesan watershed (incl. Sungai } \\
\text { Lesan protected area) }\end{array}$ & 400 & & 500 \\
\hline
\end{tabular}


TABle 1 (Continued)

\begin{tabular}{|c|c|c|c|c|}
\hline Species & Habitat unit & $\begin{array}{l}\text { Estimated no. of } \\
\text { individuals }\end{array}$ & Habitat block & $\begin{array}{l}\text { Orang-utan } \\
\text { habitat }\left(\mathrm{km}^{2}\right)\end{array}$ \\
\hline & $\begin{array}{l}\text { Kelai watershed (incl. Gunung Gajah, } \\
\text { Wehea \& several logging concessions) }\end{array}$ & 2,500 & & 4,000 \\
\hline & Sangatta-Bengalon \& Muara Wahau & 175 & & ? \\
\hline & Segah watershed & 100 & & 3,500 \\
\hline & Samarinda, Muara Badak, Marang Kayu & 200 & & $300+$ \\
\hline & Sangkulirang/Mangkalihat karst area & 750 & & 1,500 \\
\hline & Sebuku/Sembakung swamps & 100 & & 500 \\
\hline Subtotal & & 4,825 & & 10,750 \\
\hline \multirow[t]{13}{*}{ P. p. morio (in Sabah) } & Segama & $4,584(2,064-11,064)^{2}$ & & 4,630 \\
\hline & Kinabatangan & $1,125(691-1,807)^{2}$ & & 410 \\
\hline & Tabin & $1,401(517-3,796)^{2}$ & & 1,110 \\
\hline & Upper Kinabatangan & $1,716(1,016-3,403)^{2}$ & & 1,670 \\
\hline & Trus Madi forests & $282(126-736)^{2}$ & & 680 \\
\hline & Kulamba Wildlife Reserve & $500(182-1,369)^{2}$ & & 170 \\
\hline & Lingkabau Forest Reserve & $100(75-100)^{2}$ & & 300 \\
\hline & Bongayya Forest Reserve & $111(38-324)^{2}$ & & 600 \\
\hline & Sepilok & $200(100-300)^{2}$ & & 40 \\
\hline & Crocker Range National Park & $181(62-528)^{2}$ & & 900 \\
\hline & Pinangah & $223(77-644)^{2}$ & & 1,000 \\
\hline & Kuamut & $313(80-860)^{2}$ & & 5,460 \\
\hline & Ulu Kalumpang Forest Reserve & $144(54-408)^{2}$ & & 480 \\
\hline Subtotal & & $11,017(8,317-18,376)^{2}$ & & c. 17,450 \\
\hline
\end{tabular}

${ }^{1}$ The subspecific status of this population is unknown, it could be either $P$. p. pygmaeus or $P$. p. wurmbii.

${ }^{2}$ Confidence intervals from Ancrenaz et al., 2005

orang-utans, although the occasional orang-utan may travel through. The total area thus taken out of the 1999 range is $c .15,000 \mathrm{~km}^{2}$, suggesting that the actual decrease in habitat is c. $40,665 \mathrm{~km}^{2}$, i.e. $28 \%$ over 10 years, or $2.8 \%$ annually. For Sumatra, annual forest loss over 1985-2001 has been $1-1.5 \%$ annually in most orang-utan habitat (Singleton et al., 2004). We were unable to obtain data on forest loss for Sarawak but it has been estimated that coverage of primary forest in Sabah has decreased from 2.8 million to $c$. 0.3 million ha (a decrease of $89.3 \%$ ) over $1975-$ 1995 (Mannan \& Awang, 1997).

Although the rate of forest loss in some areas remains high, in other areas the loss is slowing down. For instance, in recent years forest loss in the Leuser Ecosystem in Sumatra decreased to $0.6 \%$ annually (based on SPOT imagery analysis since 1990: M. Griffiths, pers. comm.) and in East Kalimantan it has dropped from 2\% (Fuller et al., 2004) to $0.6 \%$ annually in areas where several

TAble 2 Summary of estimated population sizes of Pongo spp. in 2002 (see detailed data in Table 1), and the main threats to the four taxa.

\begin{tabular}{|c|c|c|c|}
\hline Species & Location & $\begin{array}{l}\text { No. of individuals } \\
\text { (95\% confidence interval) }\end{array}$ & Primary threats \\
\hline P. abelii & N Sumatra & c. 6,624 & Logging; road building \\
\hline \multirow[t]{2}{*}{ P.p.pygmaeus } & W Kalimantan & c. $2,000-2,500$ & Logging \& hunting \\
\hline & Sarawak & c. $1,143-1,761$ & Logging \& hunting \\
\hline P. p. wurmbii & C \& W Kalimantan & $>34,975$ & $\begin{array}{l}\text { Forest conversion; loss } \\
\text { of peat swamp forest; } \\
\text { fire; logging \& hunting }\end{array}$ \\
\hline \multirow[t]{2}{*}{ P. p. morio } & E Kalimantan & c. 4,825 & Forest conversion; hunting \\
\hline & Sabah & $11,017(8,317-18,376)^{*}$ & $\begin{array}{l}\text { Forest conversion \& } \\
\text { fragmentation }\end{array}$ \\
\hline
\end{tabular}

${ }^{*}$ Confidence interval from Ancrenaz et al., 2005 


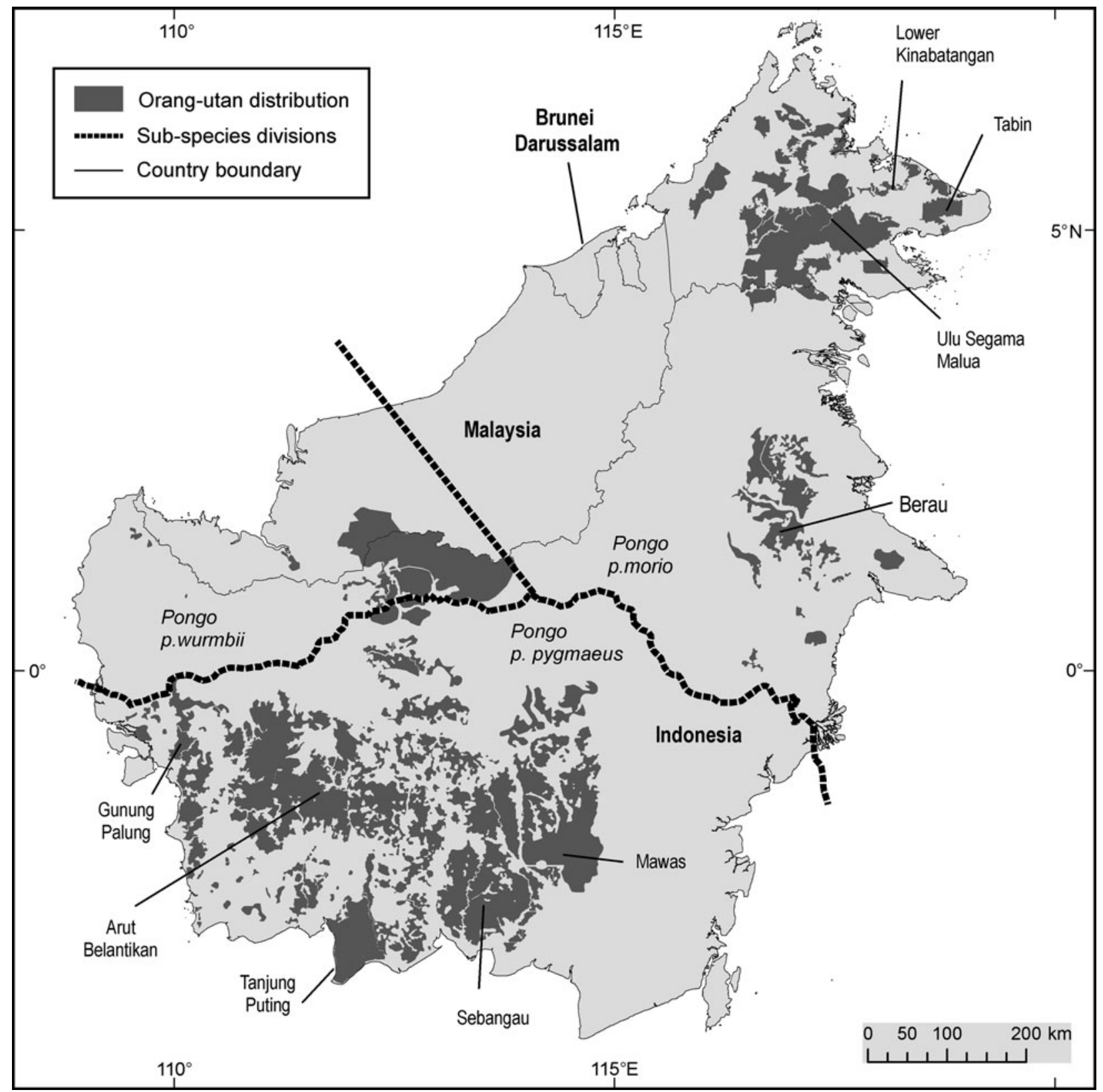

Fig. 2 Distribution of the three Bornean subspecies of orang-utan (P. pygmaeus pygmaeus, P. p. wurmbii and P. p. morio).

important orang-utan populations occur (Meijaard \& Wich, 2007).

\section{Discussion}

The data presented here highlight several important issues for orang-utan conservation. Firstly, the number of surviving orang-utans is much lower on Sumatra than on Borneo. There are only three populations on Sumatra with $>1,000$ orang-utans, whereas on Borneo there are 17. Analyses have indicated that 250 individuals is the minimum number for a viable population (Singleton et al., 2004; Marshall et al., in press) and there are only six such populations on Sumatra and 32 on Borneo. Secondly, the total estimate for Borneo is considerably higher than previously reported (Rijksen \& Meijaard, 1999). This is mainly because the earlier estimates were based on limited surveys and incomplete information. The data reported here cover several previously unsurveyed areas, such as Arut Belantikan (Fig. 2), and contain more detailed information from surveys for several other areas. It is important to emphasize that the previous estimates should have been higher, and that our data do not indicate that the reduction of Bornean orang-utans has been less severe or that the population has increased. Forest loss was high during the 2oth century and consequently the number of orang-utans that lost their habitat and subsequently died must also have been high. It is also important to note that our current orang-utan estimates are mostly based on forest 
maps from 2002, which are now 6 years old, and thus our estimates are probably too high for some areas. As a result of the political situation in Aceh Province (northern Sumatra) there has been hardly any reduction in forest cover during 2000-2006 (Gaveau et al., 2007; Meijaard \& Wich, 2007). The areas where orang-utans were previously surveyed are therefore still largely intact and it is likely that the estimate for Sumatra is accurate. A recent Borneo-wide analysis of forest cover change showed that during 20022005 annual forest loss was $1.7 \%$. Most of this loss occurs in lowland forest where the majority of orang-utans occur. Based on our own observations this trend has continued during 2005-2007, and it is thus reasonable to assume that orang-utan habitat has been lost during 2002-2008 at an annual rate of $c .1 .7 \%$. This suggests that we may have overestimated the Borneo population by $c .10 \%$.

Another fact highlighted by the collation of all available data is that $c .75 \%$ of all orang-utans occur outside national parks (Meijaard \& Wich, 2007), which have been suffering from illegal logging, mining, encroachment by palm oil plantations, and fires and have therefore been severely degraded (Nellemann et al., 2007). In many cases it appears that the appropriate authorities are either unable or reluctant to implement conservation management effectively. However, despite the general lack of law enforcement, improved protected area management can be attained. Recent examples from several sites in Kalimantan show that illegal logging in protected areas can be effectively reduced, as indicated by large reductions in illegal logging in the Sungai Wain Protection Forest (G. Fredriksson, unpubl. data), Lesan and Wehea protection forests and the Sumalindo Lestari Jaya Unit IV timber concession (EM, unpubl. data), and Gunung Palung and Sebangau National Parks (AJM \& SH, pers. obs.). Key reasons for success in Sungai Wain, Gunung Palung and Sebangau were political and financial support, media attention, and efforts by conservationists. Political and financial support mostly came from the Indonesian Government and/or international agencies although, in general, the lack of political will and financial support for conservation management by the Indonesian Government remains a concern (Rijksen \& Meijaard, 1999; Robertson \& van Schaik, 2001). Antilogging measures included eviction of illegal settlers, closure of timber transportation routes, and legally endorsed insertion of metal spikes in all commercial timber trees. In addition, in some cases the operations of community-based forest protection units have been an effective system to protect orang-utan habitat and to combat illegal hunting or trade of the species (authors, pers. obs.).

The case of Sungai Wain may be special because it is a small area that may not be representative of the complexities of conserving much larger areas. Nevertheless, we believe lessons can be learned from such small-scale conservation projects that may be applicable to larger areas.
On Sumatra most orang-utans occur in the province of Nanggroe Aceh Darussalam, both in and outside National Parks. The recent temporary moratorium on logging, put in place by the first democratically elected Acehnese Governor, is a sign that forest conservation is now on the political agenda.

In non-protected areas similar threats occur but at least on Borneo there may be opportunities to develop reduced impact logging systems that may enable orang-utans to survive in such areas. Because many orang-utans occur in forests legally exploited for timber $(>75 \%$ in Kalimantan; $>60 \%$ in Sabah) there is a need to develop forestry management practices that reduce impacts on orang-utan populations. Both orang-utan species suffer temporary density declines following reduced impact logging, $P$. abelii more so than P. pygmaeus (Rijksen, 1974; Felton et al., 2003; Morrogh-Bernard et al., 2003; Johnson et al., 2005; van Schaik et al., 2005; Marshall et al., 2006) but recover to prelogging densities if forests are allowed to regenerate (Knop et al., 2004). Recovery is helped by retaining soft-pulp fruit bearing trees and climbers, and strictly enforcing antipoaching laws (Rijksen \& Meijaard, 1999; Robertson \& van Schaik, 2001). In Sabah the Deramakot Forest Reserve, using sustainable forestry practices, harbours higher orangutan densities than areas under traditional (i.e. more destructive) forestry practices (Ancrenaz et al., 2005). Thus, if there is a significant improvement in management, timber concessions elsewhere could make an important contribution to orang-utan conservation. On Sumatra orang-utans seem to cope less well with logging and more research is needed to determine whether any level of extraction is compatible with orang-utan conservation. For orang-utans, as for chimpanzees Pan troglodytes and gorillas Gorilla gorilla in West Africa (Morgan \& Sanz, 2007), a balance between timber extraction and conservation is being sought as one option to improve conservation.

It is essential that conservation measures are taken to protect orang-utans outside national parks, and these measures will by necessity be specific to each region. In Sumatra, for example, most orang-utans occur within the boundaries of the legally protected Leuser Ecosystem, which was gazetted to protect lowland forests and incorporated the existing, mostly mountainous, Gunung Leuser National Park. Because many orang-utans occurred in the lowland forests surrounding the Gunung Leuser National Park the Leuser Ecosystem has provided formal protection to a much larger number of orang-utans (Singleton et al., 2004). Creating such alternatives to national parks, where more local management is involved, may create local support for conservation, which is thought to be essential for success (Ancrenaz et al., 2007). Similar efforts are now under way in large $(>1.5$ million ha) multifunction landscapes in West Kalimantan (Ketapang District) and East Kalimantan (Kelai and Lesan watersheds). 
Although timber extraction can in certain situations be compatible with orang-utan conservation, complete conversion of forest to plantations is generally not so. There are reports of orang-utans surviving and, in the short-term, seemingly thriving in or near monocultures of Acacia spp. (Marshall et al., 2007; EM, pers. obs.) but generally timber and oil palm plantations appear not to provide viable orang-utan habitat. By far the greatest present threat is the impact on the forest from the expanding palm oil industry. Indonesia and Malaysia are the two largest palm oil producers, with a combined $80.5 \%$ share of global production (FAOSTAT, 2006). The rapid expansion of this industry is putting great pressure on the forest (Pin Koh \& Wilcove, 2007). A large number of new plantations are being created in recently logged forest areas, whereas they could be established on already degraded land (Venter et al., 2007). In cases where this is not possible and plantations are created on forested land, mechanisms are required by which conservationists can advise the oil palm industry and other land developers on where to leave wildlife corridors.

In addition, much forest conversion and degradation stems from poor land-use planning. For example, in Sumatra, the controversial Ladia Galaska road project in the Leuser Ecosystem will, unless halted, fragment two of the three largest remaining orang-utan populations. The effect of this road network can be predicted from that of a similar road project, in 1982, which split the Gunung Leuser National Park. Monitoring showed that the improved access facilitated uncontrolled illegal settlements inside the Park, large-scale illegal encroachment and logging, and poaching of threatened species (Singleton et al., 2004). The mega rice project in Central Kalimantan, funded primarily by Indonesia's reforestation fund, eliminated $c .10,000 \mathrm{~km}^{2}$ of primary peat swamp forest and killed an estimated 15,000 orang-utans from 1996 to 1999 (EIA, 1998; Rijksen \& Meijaard, 1999). Both are examples of illadvised projects with few benefits to local economies but major environmental costs. However, as such projects provide substantial revenue for a small group of individuals with considerable political influence, unprecedented political will is needed to prevent similar projects in the future.

Hunting of orang-utans, which is prohibited throughout their range, is potentially a major factor contributing to their decline (Marshall et al., 2006). Because orang-utan populations have such a slow growth rate they are unable to sustain substantial continued loss of individuals (Singleton et al., 2004; Marshall et al., in press). A decline in orangutan populations through hunting is especially likely in areas where agriculture is encroaching into orang-utan habitat and where human-orang-utan conflicts occur, and in areas where orang-utans are hunted for food, such as logging concessions (Bennett et al., 1999, 2002). Such problems have led to a huge influx of orang-utans into rehabilitation centres, especially on Borneo.
Based on this review and our experience in Sumatra and Borneo, we make seven recommendations to reduce hunting and human-orang-utan conflict in agricultural areas (cf. Yuwono et al., 2007) and for orang-utan conservation in general: (1) Effective law enforcement and prosecution is needed to stop hunting of orang-utans for food and trade. (2) Mechanisms need to be developed to mitigate and reduce human-orang-utan conflict in agricultural areas, including large-scale plantations (cf. Yuwono et al., 2007). (3) Audits are required to assess the compliance of forestry concessions to their legal obligation to ensure orang-utans are not hunted in concession areas. (4) Increased environmental awareness is needed at a local level (several NGOs, such as the Sumatran Orang-utan Conservation Program and Kinabatangan Orang-utan Conservation Project, are promoting awareness of the conservation of forests and their biodiversity). (5) Mechanisms for monitoring orangutan populations and forest cover need to be developed (implementation of such monitoring is beginning on both Sumatra and Borneo, and there are initiatives under way to guide such monitoring for great apes in general; A.P.E.S. Database, 2008). (6) Surveys in less-explored regions such as Sarawak need to be continued. (7) Improved survey methodology is required and nest decay rate needs to be determined for more sites as it can vary substantially (Mathewson et al., 2008; Husson et al., in press).

All efforts to monitor orang-utans will, however, be to no avail unless the decline in numbers is halted, and this requires a change in political will (Rijksen \& Meijaard, 1999). The Indonesian President recently launched the Indonesian National Orang-utan Conservation Action Plan. This was prepared by the Ministry of Forestry, with contributions from several of the authors of this article, and for which the orang-utan numbers presented here were used (Soehartono et al., 2007). Another sign of changing political will and action is the current moratorium on logging in Aceh Province, where by far the largest number of Sumatran orang-utans occur. Here and in other areas new incentives for forest protection could be tested, e.g. payments for environmental services such as water, carbon sequestration and avoided deforestation (Stern, 2007; Wunder, 2007). In combination with the above mentioned recommendations these may improve forest and orangutan protection. However, it is essential that funding for environmental services reaches the local level and that there is strong law enforcement. Developing a mechanism to ensure these occur is the challenge for the conservation of orang-utans.

\section{Acknowledgements}

We gratefully acknowledge the co-operation and support of the Indonesian Institute of Science, Jakarta, the Indonesian Nature Conservation Service, Jakarta (and at the various 
local offices involved). In addition, SAW thanks the Fauna \& Flora International Aceh programme for which the recent surveys in Aceh were conducted. We thank the Conservation Breeding Specialist Group for organizing the 2004 workshop, and the Gibbon Foundation for funding it. Thanks to the Unit Management Leuser for providing LANDSAT images, Nick Jewell for digitizing the Sumatran vegetation maps, and Doug Fuller for providing the MODIS images.

\section{References}

Ancrenaz, M. (2007) Consultancy on Survey Design and Data Analysis at Betung Kerihun National Park, Indonesia. WWFGermany, Berlin, Germany.

Ancrenaz, M., Dabek, L. \& O'Neil, S. (2007) The costs of exclusion: recognizing a role for local communities in biodiversity conservation. PLoS Biology, 5, e289.

Ancrenaz, M., Gimenez, O., Ambu, L., Ancrenaz, K., Andau, P., Goossens, B. et al. (2005) Aerial surveys give new estimates for orang-utans in Sabah, Malaysia. PLoS Biology, 3, e3.

A.P.E.S. Database (2008) IUCN/Species Survival Commission Primate Specialist Group and Department of Primatology, Max Planck Institute for Evolutionary Anthropology, Leipzig, Germany. Http://apes.eva.mpg.de/ [accessed 29 April 2008].

BACON, A.M. \& Long, V.T. (2001) The first discovery of a complete skeleton of a fossil orang-utan in a cave of Hao Binh province. Journal of Human Evolution 41, 227-242.

Barber, C.V., Matthews, E., Brown, D., Brown, T.H., Curran, L. \& Plume, C. (2002) The State Of The Forest: Indonesia. Forest Watch Indonesia, Global Forest Watch \& World Resources Institute, Washington, DC, USA[http://forests.wri.org/ pubs_pdf.cfm?PubID = 3147, accessed 4 April 2008].

Bennett, E.L., Milner-Gulland, E.J., Bakarr, M., Eves, H.E., Robinson, J.G. \& Wilkie, D.S. (2002) Hunting the world's wildlife to extinction. Oryx, 36, 328-329.

Bennett, E.L., Nyaoi, A.J. \& Sompud, J. (1999) Saving Borneo's bacon: the sustainability of hunting in Sarawak and Sabah. In Hunting for Sustainability in Tropical Forests (eds J.G. Robinson \& E.L. Bennett), pp. 305-324. Columbia University Press, New York, USA.

EIA (Environmental Investigation Agency) (1998) The Politics of Extinction: The Orang-utan Crisis and the Destruction of Indonesia's Forests. EIA, London, UK.

FAOSTAT (2006) Http://faostat.fao.org [accessed 1 May 2006].

Felton, A.M., Engstrom, L.M., Felton, A. \& Knott, C.D. (2003) Orang-utan population density, forest structure and fruit availability in hand-logged and unlogged peat swamp forests in West Kalimantan, Indonesia. Biological Conservation, 114, 91-101.

Fuller, D.O., Jessup, T.C. \& Salim, A. (2004) Loss of forest cover in Kalimantan, Indonesia, since the 1997-1998 El Niño. Conservation Biology, 18, 249-254.

Galdikas, B.M.F. \& WOOD, J.W. (1990) Birth spacing patterns in humans and apes. American Journal of Physical Anthropology, 83, 185-191.

Gaveau, D.L.A., Epting, J., Adnan, B., Kumara, I., Suyikno, B. \& Sumantri, H. (2007) Deforestation Map (1990-2006) of Northern Sumatra at 150,00o Scale. Interactive CD-ROM. Wildlife Conservation Society Indonesia Program, Conservation International \& Directorate General of Forest Protection and Nature Conservation, Bogor, Indonesia.
Goossens, B., Chikhi, L., Ancrenaz, M., Lackman-Ancrenaz, I., Andau, P. \& Bruford, M.W. (2006) Genetic signature of anthropogenic population collapse in orang-utans. PLoS Biology, 285-291, e225.

Groves, C.P. (2001) Primate Taxonomy. Smithsonian Institution Press, Washington, DC, USA.

Harvey, P.H., Martin, R.D. \& Clutton-Brock, T.H. (1987) Life histories in comparative perspective. In Primate Societies (eds B.B. Smuts, D.L. Cheney, R.M. Seyfarth, R.W. Wrangham \& T.T. Struhsaker), pp. 181-196. The University of Chicago Press, Chicago, USA.

Holmes, D. (200o) Deforestation in Indonesia. A Review of the Situation in 1999. World Bank, Jakarta, Indonesia.

Husson, S.J., Wich, S.A., Marshall, A.J., Dennis, R.D., Ancrenaz, M., Brassey, R. et al. (in press) Orang-utan distribution, density, abundance and impacts of disturbance. In Orang-utans: Geographic Variation in Behavioral Ecology (eds S.A. Wich, S.S. Utami Atmoko, T. Mitra Setia \& C.P. van Schaik). Oxford University Press, Oxford, UK.

IUCN (2007) 2007 IUCN Red List of Threatened Species. IUCN, Gland, Switzerland. Http://www.iucnredlist.org [accessed 4 April 2008].

Jepson, P., Jarvie, J.K., MacKinnon, K. \& Monk, K.A. (2001) The end for Indonesia's lowland forests? Science, 292, 859-861.

Johnson, A.E., Knott, C.D., Pamungkas, B., Pasaribu, M. \& Marshall, A.J. (2005) A survey of the orang-utan (Pongo pygmaeus wurmbii) population in and around Gunung Palung National Park, West Kalimantan, Indonesia based on nest counts. Biological Conservation, 121, 495-507.

KNOP, E., Ward, P.I. \& W ICH, S.A. (2004) A comparison of orangutan density in a logged and unlogged forest on Sumatra. Biological Conservation, 120, 187-192.

Leighton, M., Seal, U.S., Soemarna, K., Adjisasmito, M. Wijaya, T., Mitra Setia, T. et al. (1995) Orang-utan life history and VORTEX analysis. In The Neglected Ape (eds R.D. Nadler, B.M.F. Galdikas, L.K. Sheeran \& N. Rosen), pp. 97-107. Plenum Press, New York, USA.

Mannan, S. \& Awang, Y. (1997) Sustainable Forest Management in Sabah. Sabah Forestry Department for the 'Seminar on Sustainable Forest Management' 22 November 1997, Kota Kinabalu, Malaysia.

Marshall, A.J., Lacy, R., Ancrenaz, M., Byers, O., Husson, S., Leighton, M. et al. (in press) Orang-utan population biology, life history, and conservation: perspectives from PVA models. In Orang-utans: Geographic Variation in Behavioral Ecology (eds S.A. Wich, S.S. Utami Atmoko, T. Mitra Setia \& C.P. van Schaik). Oxford University Press, Oxford, UK.

Marshall, A.J., Nardiyono, Engström, L.M., Pamungkas, B., Palapa, J., Meijaard, E. \& Stanley, S.A. (2006) The blowgun is mightier than the chainsaw in determining population density of Bornean orang-utans (Pongo pygmaeus morio) in the forests of East Kalimantan. Biological Conservation, 129, 566-578.

Marshall, A.J., Salas, L.A., Stephens, S., Nardiyono, Engström, L.M., Meijaard, E. \& Stanley, S. (2007) Use of limestone karst forests by Bornean orang-utans (Pongo pygmaeus morio) in the Sangkulirang Peninsula, East Kalimantan, Indonesia. American Journal of Primatology, 69, 1-8.

Mathewson, P.D., Spehar, S.N., Meijaard, E., Nardiyono, Purnomo, S ASmirul, A. et al. (2008) Evaluating orang-utan census techniques using nest decay rates: implications for population estimates. Ecological Applications, 18, 208-221.

Meijaard, E. \& Wich, S.A. (2007) Putting orang-utan population trends into perspective. Current Biology, 17, R540. 
Morgan, D. \& S AnZ, C. (2007) Best Practice Guidelines for Reducing the Impact of Commercial Logging on Great Apes in Western Equatorial Africa. IUCN/Species Survival Commission Primate Specialist Group, Gland, Switzerland [http://www.primate-sg.org/ PDF/BP.logging.pdf, accessed 7 April 2008].

Morrogh-Bernard, H., Husson, S., Page, S.E. \& Rieley, J.O. (2003) Population status of the Bornean orang-utan (Pongo pygmaeus) in the Sebangau peat swamp forest, Central Kalimantan, Indonesia. Biological Conservation, 110, 141-152.

Nellemann, C., Miles, L., Kaltenborn, B.P., Virtue, M. \& Ahlenius, H. (eds) (2007) The Last Stand of the Orang-utan - State of Emergency: Illegal Logging, Fire and Palm Oil in Indonesia's National Parks. UN Environment Programme, GRID-Arendal, Norway.

Pin Koh, L. \& Wilcove, D.S. (2007) Cashing in palm oil for conservation. Nature, 448, 993-994.

RIJKSEN, H.D. (1974) Orang-utan conservation and rehabilitation in Sumatra. Biological Conservation, 6, 20-25.

Rijksen, H.D. \& Meijanad, E. (1999) Our Vanishing Relative: The Status of Wild Orang-utans at the Close of the Twentieth Century. Kluwer Academic Publishers, Dordrecht, The Netherlands.

Robertson, J.M.Y. \& VAN SCHAiK, C.P. (2001) Causal factors underlying the dramatic decline of the Sumatran orang-utan. Oryx, 35, 26-38.

Singleton, I. \& VAn SCHAik, C.P. (2001) Orang-utan home range size and its determinants in a Sumatran swamp forest. International Journal of Primatology, 22, 877-911.

Singleton, I., Wich, S.A., Husson, S., Stephens, S., Utami-Atmoko, S.S., Leighton, M. et al. (eds) (2004) Orang-utan Population and Habitat Viability Assessment: Final Report. IUCN/Species Survival Commission Conservation Breeding Specialist Group, Apple Valley, USA.

Soemartono, T., Djoko Susilo, H., Andayani, N., Utami Atmoko, S.S., Sinite, J., Saleh, C. \& Sutrisno, A. (2007) Strategi dan Rencana Aksi Konservasi orang-utan Indonesia 20072017. Departemen Kehutanan, Jakarta, Indonesia.

Stern, N. (2007) The Economics of Climate Change: The Stern Review. Cambridge University Press, Cambridge, UK.

Van SChaik, C.P., Monk, K.A. \& Robertson, J.M.Y. (2001) Dramatic decline in orang-utan numbers in the Leuser Ecosystem, Northern Sumatra. Oryx, 35, 14-25.

van Schaik, C.P., Priatna, A. \& Priatna, D. (1995) Population estimates and habitat preferences of orang-utans based on line transects of nests. In The Neglected Ape (eds R.D. Nadler, B.M.F. Galdikas, L.K. Sheeran \& N. Rosen), pp. 129-147. Plenum Press, New York, USA.

VAn Schaik, C.P., Wich, S.A., Utami, S.S. \& Odom, K. (2005) A simple alternative to line transects of nests for estimating orang-utan densities. Primates, 46, 249-254.
Venter, O., Meijaard, E. \& Wilson, K. (2007) Strategies and alliances needed to protect forest from palm-oil industry. Nature, $451,16$.

von Koeningswald, G.H.R. (1982) Distribution and evolution of the orang-utan, Pongo pygmaeus (Hoppius). In The orang-utan, its Biology and Conservation (ed. L.E.M. de Boer), pp. 1-15. Dr W. Junk Publishers, The Hague, The Netherlands.

Warren, K.S., Verschoor, E.J., Langenhuijzen, S., Heriyanto, Swan, R.A., Vigilant, L. \& Heeney, J.L. (2001) Speciation and intrasubspecific variation of Bornean orang-utans, Pongo pygmaeus pygmaeus. Molecular Biology and Evolution, 18, 472-480.

WICH, S.A. (2007) Orang-utan Survey Report to Fauna \& Flora International. Unpublished report for Fauna \& Flora International, Banda Aceh, Indonesia.

Wich, S., Buij, R. \& van Schaik, C.P. (2004a) Determinants of orang-utan density in the dryland forests of the Leuser Ecosystem. Primates, 45, 177-182.

Wich, S.A., Singleton, I., Utami-Atmoko, S.S., Geurts, M.L., Rijksen, H.D. \& van SCHAik, C.P. (2003) The status of the Sumatran orang-utan Pongo abelii: an update. Oryx, 37, 49-54.

Wich, S.A., Ut ami- A тмоко, S.S., Setia, T.M., Rijksen, H.D., SCHÜrmann, C. \& van SChaik, C.P. (2004b) Life history of wild Sumatran orang-utans (Pongo abelii). Journal of Human Evolution, 47, 385-398.

W UndER, S. (2007) The efficiency of payments for environmental services in tropical conservation. Conservation Biology, 21, $48-58$.

Yuwono, E.H., Susanto, P., Saleh, C., Andayani, N., Prasetyo, D. \& Uтамі Атмоко, S.S. (2007) Guidelines for the Better Management Practices on Avoidance, Mitigation and Management of Human-orang-utan Conflict in and around Oil Palm Plantations. WWF-Indonesia, Jakarta, Indonesia.

\section{Biographical sketches}

The 16 authors represent a wide range of disciplines related to the conservation of the various orang-utan taxa, including behavioural ecology, ecology, remote sensing, geographical information systems, conservation science and population modelling. The 2004 orang-utan workshop in Jakarta, from which this article developed, provided the opportunity for us to share information so that we could compile the most up-to-date and accurate data on the distribution and density of both Sumatran and Bornean orang-utans. Such an integrative approach is essential to assess the conservation status of the various taxa, model future scenarios, and develop appropriate and realistic conservation strategies. 